\title{
Coping with Racism: a Perspective of COVID-19 Church Closures on the Mental Health of African Americans
}

\author{
Flavia DeSouza ${ }^{1}$. Carmen Black Parker ${ }^{1}$ (D) - E. Vanessa Spearman-McCarthy ${ }^{2} \cdot$ Gina Newsome Duncan $^{3}$. \\ Reverend Maria Myers Black ${ }^{4}$
}

Received: 6 August 2020 / Revised: 11 September 2020 / Accepted: 28 September 2020 / Published online: 2 October 2020

(C) W. Montague Cobb-NMA Health Institute 2020

\begin{abstract}
Academic medical literature and news outlets extensively document how older individuals in communities of color, especially African American communities, are dying disproportionately of COVID-19 due to ongoing societal, racial, and healthcare disparities. Fear of death and suffering are acutely elevated in Black communities; yet, African Americans have been facing, coping with, and overcoming American societal racism and subsequent detriments to our mental health for centuries. Predominately African American churches (hereafter referred to as the "Black Church") have always served a historical, cultural, contextual, and scientifically validated role in the mental health well-being of African American communities coping with American racism. Nonetheless, buildings of worship closed due to the COVID-19 pandemic in mid-March 2020. This article is a first-hand perspective of five Black internists/psychiatrists who are deeply involved in both academic medicine and leadership positions within the Black Church. It will explore how the physical closure of Black Churches during this period of increased mental stress, as caused by healthcare inequities revealed by the COVID-19 epidemic, is likely to be uniquely taxing to the mental health of African Americans, particularly older African Americans, who must cope with American racism without physical access to the Black Church for the first time in history.
\end{abstract}

Keywords COVID-19 $\cdot$ Church $\cdot$ Religion $\cdot$ African American $\cdot$ Black $\cdot$ Racism

I, Reverend Dr. Maria Black, write today as an ordained minister in the African Methodist Episcopal (AME) Church, an older African American woman, and a board-certified internist with nearly 40 years of experience in general and academic medicine in Georgia. I write alongside my daughter, Dr. Carmen Black Parker; my lifelong friend and AME Church member, Dr. E. Vanessa Spearman-McCarthy; and my friends, Drs. Gina Duncan and Flavia DeSouza. We all

Carmen Black Parker

carmen.parker@yale.edu

1 Department of Psychiatry, Yale University School of Medicine, New Haven, CT, USA

2 Department of Psychiatry and Health Behavior, Medical College of Georgia, Augusta University, Augusta, GA, USA

3 Eastover Psychological and Psychiatric Group, P.A, Charlotte, NC, USA

4 African Methodist Episcopal Church, Augusta, GA, USA identify as Christian Black women and are all practicing internists and/or psychiatrists.

We have been struck by the breadth of the racial disparities that African Americans, especially older African Americans, face during this COVID-19 pandemic in the USA. COVID-19 does not discriminate by race or ethnicity. However, older individuals in communities of color are dying disproportionately due to ongoing societal, racial, and healthcare disparities poised against us [1]. Fear of death and suffering are acutely elevated in Black communities; yet, Black communities are no stranger to systemic racism or healthcare disparities. Black churchgoers have always had physical access to the Church and have used this deep-rooted cultural and religious establishment to cope with the psychological and social effects of racism. Like many African American church leaders around the country, Bishop Reginald T. Jackson asked all AME pastors and churches in Georgia at the beginning of this pandemic to abide by national and state guidelines to not hold in-person worship services because "...[Our] first priority is the safety and well-being of the congregants." Thus, our church buildings first closed due to the COVID-19 pandemic in mid- 
March 2020. Even as churches physically reopen in the weeks and months to come, continued physical distancing and caution regarding contact with others will drastically change the pattern of utilization of the Church and the daily operation of services. We, the authors, hope to foster awareness of how the COVID-19 closures of predominately African American churches (hereafter referred to as the "Black Church"), for the first time in history, will uniquely and negatively impact the mental health of African Americans, especially older African Americans, as we continue to cope with the societal effects of racism on our communities. We also seek to provide recommendations for our colleagues who work with this vulnerable population.

\section{Racism and the Historical, Cultural, Contextual Significance of Black Churches}

Black Churches were some of the earliest real estate ever owned by African Americans. There, we could function somewhat autonomously. The AME Church, for example, was founded in Philadelphia by freed slaves in 1787 so we could worship without racial discrimination [2]. After the Civil War, churches met the educational needs of emancipated slaves by establishing schools and colleges in their basements. Even today, Black Churches teach children about our heritage and accomplishments when Black history is often not taught in schools, or perhaps is taught from a text or from an educator who does not understand the African American perspective of these historical events [3]. During segregation, we could not dine at local restaurants and were often barred from concerts given in white venues, even when the artists themselves were Black. So, the Church became our dining and concert hall. Civil rights strategies were developed in Black Churches, and many older Black patients have vivid memories of these days. Even today in the racial unrest resulting from George Floyd's death, many of the demonstrations against police brutality in Black communities are spearheaded by prominent religious leaders in the Black Church. Our sanctuaries are both sacred places and places of physical and psychological refuge from the prejudice, discrimination, and mistreatment we experience in American society.

My multifaceted identity as a minister, internist, and older African American has provided many occasions to listen to and understand the perspective of many older African Americans. Geriatric Black patients have lived through more experiences of societal and medical racism than any other demographic by virtue of our age and ethnicity. This includes living through an era when the US government experimented on our Black men in Tuskegee, Alabama, for over 40 years, until the study's public disclosure in 1972 [4]. Many older African Americans cannot explicitly describe Tuskegee's details, but collective mistrust of the medical establishment is deeply entrenched within Black culture [5]. Because of the historical and cultural significance of the Church, Black communities have trusted our ministers and other faith-based leaders when we could not trust our government and medical providers. I have had the opportunity, and felt charged, to provide my church community with scientifically sound medical information while being sensitive to their legitimate concerns about the medical community at large. Given the impact of COVID-19 on our community, I believe it is critical to also share my perspective with my colleagues in medicine. The historical and social context of coping with racism sets the stage for our continued reliance upon the Church for our mental well-being during this pandemic.

\section{Importance of the Black Church in Coping with Racism}

Traditional Black worship experiences serve a cathartic and therapeutic purpose. Upbeat gospel songs are sung by the choir accompanied by drums and guitar. Congregations enthusiastically sing and clap with the choir, even dancing at times. We warmly embrace. You will hear passionate "call and response" sermons where congregants are encouraged (and sometimes expected) to respond by enthusiastically saying "Amen!" or "So true!" or "Preach preacher!" Congregants may have dealt with systemic issues such as racial prejudice, workplace and wage discrimination, and inadequate healthcare all week. On Sunday mornings, however, we find an environment of empowerment, healing, and even rejoicing.

Racism and discrimination increase the prevalence and frequency of many physical and psychiatric disorders in African Americans, notably older African Americans [6, 7]. These detriments to physical and mental health are possibly caused by stress-mediated changes including immune and inflammatory dysregulation [8] and dysfunction of the hypothalamicpituitary-adrenal (HPA) axis [7]. Moreover, older African Americans perceive more daily discrimination than our Caucasian peers [9]. Not only do we perceive discrimination, the harrowing statistics of the unequal devastation of COVID19 on our communities exemplifies that this racism is real. Additionally, a 2015 meta-analysis of 293 studies reported that racism negatively impacts both physical and mental health, with evidence that racism harms mental well-being twice as much as physical well-being after controlling for publication bias [7]. Of interest, the study's authors found that African Americans were more resilient in the face of ongoing societal racism than Hispanic and Asian individuals. Experientially speaking, I believe that our cultural adaptation and reliance upon the Black Church strongly contributes to this resilience. Furthermore, science validates the benefits of church attendance and prayer to the physical and mental health of African Americans [10-12]. For example, group 
singing releases endorphins, elevates pain thresholds, increases social bonding, augments immune competence, and may even benefit cognition in older adults [13-15].

One possible drawback to our reliance upon churches for our mental health, however, is the possibility of developing negative religious coping [16]. Identified spiritual struggles include feeling angry at God, attributing difficulties to demonic forces, negative interactions with other believers, experiencing internal guilt, and doubting one's faith $[16,17]$. Indeed, I have counseled congregants with depression who harbor beliefs like, "No Christian should ever feel depressed" or "Feeling sad means that I don't have enough faith in God." Though negative religious coping may paradoxically exacerbate mental distress when these spiritual struggles arise, evidence suggests that these struggles may be less problematic for Black individuals as compared to those who are White or Hispanic [17].

Overall, older African Americans do not seek professional mental health services as frequently as our peers [18, 19]. Furthermore, our attempts to share the realities of racism and mistrust in our lives with healthcare providers risk being misinterpreted as pathological paranoia and/or psychosis. Thus, our community, especially our Black men, is overdiagnosed with psychotic illnesses like schizophrenia, especially paranoid schizophrenia $[20,21]$. These ongoing treatment disparities and the historical context of societal racism influence our decisions to often turn to religious leaders for our mental health instead of medical providers. This pandemic is unlikely to change our utilization patterns. Yet, for the first time in our history, African Americans must cope with the contextually valid fears of COVID-19 without physical access to our religious havens to alleviate mental distress. We, the authors, are noticing that many older African Americans are (appropriately) fearful of ongoing COVID-19 risks even after churches have reopened, and so may feel it necessary to continue to physically distance themselves from what has been an important coping mechanism. We even have due cause to fear congregating for our traditional religious services to bury our loved ones who are unjustly dying to COVID-19. How can communities and providers work together to overcome these obstacles?

\section{Overcoming the Negative Impact of COVID-19 Church Closures}

Though loss is a disproportionately heartbreaking reality in Black communities during COVID-19, patients may not share their grief unless providers directly ask. The first and possibly most important step for providers is to learn to recognize and validate the unique role that American societal racism may serve in exacerbating the mental and physical health of our Black patients during this time. Therefore, it is critical for providers to acknowledge the realities of racism and discrimination as social determinants of health [7] so that we may develop competency in addressing them in real time. Remaining mindful of the social and historical context of coping with racism also facilitates providers beginning to understand the context to our differential expressions of mental health concerns and possible mistrust of certain clinical recommendations.

Providers should remain mindful that the language that older African Americans use to express depression may differ from the items on questionnaires commonly used to screen for depression in both primary care and mental health settings. Older, church-going African Americans are more likely to express irritability, social isolation, loneliness, and loss of control [22]. In my experience, religious Black individuals may have difficulty internally recognizing that we are anxious or sad at all. In instances when mental health concerns are accurately detected, providers may possibly encounter resistance and/or suspicion when recommending that a Black patient seek formal mental healthcare. These are opportunities to refrain from pathologizing culturally-relevant instances of mistrust in real-time clinical encounters. Please remain mindful of the historical, cultural, and contextual experiences of Black individuals facing medical racism, especially during the COVID-19 era, as it relates to our cultural treatment preferences relying more heavily on spiritual interventions. Authors in South Africa have similarly encouraged healthcare providers to maintain a holistic approach to wellness during this pandemic that prioritizes spiritual care even after our treatment practices have transitioned from physical clinical settings to virtual settings [23]. Like a hospital chaplain provides spiritual counsel without endorsing any particular religion, providers are able to explore whether a faith-based and/or spiritual-based treatment alternative would be more amenable to patients in need of support while coping with racism, COVID-19 inequalities, depression, grief, and anxiety.

Now more than ever, healthcare providers can encourage older Black patients to prioritize spiritual health alongside physical and mental health. For example, Black Churches are proud to serve some of the country's poorest rural and urban Black communities, yet many of these churches may have limited access to devices capable of videoconferencing and converting to an online platform. Therefore, providers can engage patients in problem-solving technological challenges. Perhaps your clinic has a social worker or can recruit a family member to assist patients with technology. Perhaps the patient's home church is not online, but a sister church can serve as an interim substitute for their spiritual needs. Please consider spirituality and religious leaders as out treatment allies and encourage regular communication between church leaders and members.

In light of the growing mental health needs of congregants who may possess little access to formal mental health 
providers and/or may have previously experienced aversive interactions with mental health providers, we have initiated a series of faith-based webinars to facilitate dialog and promote better coping with the mental health issues of discrimination and loss during the COVID-19 pandemic and beyond. Presentations have also been accessible by phone for those lacking more sophisticated technologies. We have been inviting congregants and clergy members of several Black Church denominations, affiliates from historically Black colleges and universities, and professional colleagues who wish to learn more about our culture for their own clinical practice. Grounded in our historical context, the webinars illuminate and provide appropriate language around mental health issues in the Black community. We empower participants to seek help from trusted and reputable sources while also openly sharing common mental health treatment and diagnostic disparities meriting awareness, such as medicine's tendency to label our affective experiences as psychotic instead of depressed [21]. Consistent with the literature [16, 17], we dedicate a significant portion of the webinars to address spiritual and cultural myths, stigma, and beliefs that may contrastingly pose a barrier to acknowledging mental health concerns. Grassroots, religious-based webinars like this one that target mental health concerns within the Black Church during COVID-19 are thankfully arising with increasing frequency across the country.

In addition to platforms geared towards Black individuals who identify with the Christian faith, let us not forget the diversity of spiritual faiths amongst Black individuals in the United States. Organizations like The National Black Muslim COVID Coalition merit recognition for meeting the spiritual needs of Black Americans during this pandemic through webbased platforms [24]. In fact, spiritual organizations across the world are brainstorming ways to meet the spiritual needs of a diverse body of believers. For example, health professionals in Brazil created a Spiritual Hotline to virtually assist the spiritual needs of its people, including those of different religions and nationalities [25]. Similarly, the Roman Catholic Church launched a social media campaign in the Philippines to help its congregants cope with COVID-19 [26]. While we maintain our first-hand perspective that the Black Christian Church has been uniquely significant in the lives of African Americans because of the physical and mental detriments of American racism since slavery, we also wish to reflect that we are a body of spiritual believers who are transcending the boundaries of countries, religious affiliations, and cultural backgrounds in order to take a unified stance of wellness and racial resilience against COVID-19.

Providers may serve a critical role by simply validating our Black patients' concerns, by being aware that faith-based interventions exist with scientifically-validated benefits, and by encouraging patients to explore what offerings are available in their communities. There are also numerous ways that interested providers may volunteer a more in-depth participation with faith-based interventions, if desired. As opposed to waiting to be approached by a local faith-based institution, we encourage providers to initiate dialog with an email or phone call. While we as providers may or may not share a cultural or spiritual background with these various organizations, we are able to introduce ourselves and humbly offer our assistance and medical expertise to congregations. Perhaps congregations have already recognized the need for medical and mental health assistance but lacked the expertise to facilitate a formal resource to their members. No matter the reason, providers may join and/or create collaborations with faith-based initiatives beginning with as little as a phone call or email.

\section{Conclusion}

Black Churches promote spiritual renewal alongside mental resiliency and coping against societal racism, especially for older African Americans. The physical closure of churches during this period of increased mental stress, as caused by healthcare inequities revealed by the COVID-19 epidemic, is likely to cause immediate and long-term detrimental effects on this population. We call on all clinicians to be mindful of this issue and develop appropriate management plans with and for their older African American patients.

\section{Compliance with Ethical Standards}

Conflict of Interest The authors declare that they have no conflict of interest.

Ethical Approval This article does not contain any studies with human participants or animals performed by any of the authors.

\section{References}

1. Laurencin CT, McClinton A. The COVID-19 pandemic: a call to action to identify and address racial and ethnic disparities. J Racial Ethn Health Disparities. 2020;7:398-402. https://doi.org/10.1007/ s40615-020-00756-0.

2. African Methodist Episcopal Church. Our history. The Official Website of the African Methodist Episcopal Church. https://www. ame-church.com/our-church/our-history/. Accessed April 15, 2020.

3. Anderson M. What kids are really learning about slavery. The Atlantic. https://www.theatlantic.com/education/archive/2018/02/ what-kids-are-really-learning-about-slavery/552098/. Accessed May 28, 2020.

4. Alsan M, Wanamaker M. Tuskegee and the health of black men. Q J Econ. 2018;133(1):407-55. https://doi.org/10.1093/qje/qjx029.

5. Suite DH, La Bril R, Primm A, Harrison-Ross P. Beyond misdiagnosis, misunderstanding and mistrust: relevance of the historical perspective in the medical and mental health treatment of people of color. J Natl Med Assoc. 2007;99(8):879-85.

6. Mouzon DM, Taylor RJ, Keith VM, Nicklett EJ, Chatters LM. Discrimination and psychiatric disorders among older African 
Americans. Int J Geriatr Psychiatry. 2017;32(2):175-82. https:// doi.org/10.1002/gps.4454.

7. Paradies Y, Ben J, Denson N, Elias A, Priest N, Pieterse A, et al. Racism as a determinant of health: a systematic review and metaanalysis. PLoS One. 2015;10(9):e0138511. https://doi.org/10. 1371/journal.pone.0138511.

8. Thames AD, Irwin MR, Breen EC, Cole SW. Experienced discrimination and racial differences in leukocyte gene expression. Psychoneuroendocrinology. 2019;106:277-83. https://doi.org/10. 1016/j.psyneuen.2019.04.016.

9. Barnes LL, Mendes De Leon CF, Wilson RS, Bienias JL, Bennett DA, Evans DA. Racial differences in perceived discrimination in a community population of older blacks and whites. J Aging Health. 2004;16(3):315-37. https://doi.org/10.1177/0898264304264202.

10. Bradshaw M, Kent BV. Prayer, attachment to god, and changes in psychological well-being in later life. J Aging Health. 2018;30(5): 667-91. https://doi.org/10.1177/0898264316688116.

11. Chatters LM, Bullard KM, Taylor RJ, Woodward AT, Neighbors HW, Jackson JS. Religious participation and DSM-IV disorders among older African Americans: findings from the National Survey of American life. Am J Geriatr Psychiatry. 2008;16(12): 957-65. https://doi.org/10.1097/JGP.0b013e3181898081.

12. Wharton T, Watkins DC, Mitchell J, Kales H. Older, Church-going African Americans' attitudes and expectations about formal depression care. Res Aging. 2018;40(1):3-26. https://doi.org/10.1177/ 0164027516675666.

13. Diaz Abrahan V, Shifres F, Justel N. Cognitive benefits from a musical activity in older adults. Front Psychol. 2019;10:652. https://doi.org/10.3389/fpsyg.2019.00652.

14. Kreutz G, Bongard S, Rohrmann S, Hodapp V, Grebe D. Effects of choir singing or listening on secretory immunoglobulin A, cortisol, and emotional state. J Behav Med. 2004;27(6):623-35. https://doi. org/10.1007/s10865-004-0006-9.

15. Weinstein D, Launay J, Pearce E, Dunbar RI, Stewart L. Group music performance causes elevated pain thresholds and social bonding in small and large groups of singers. Evol Hum Behav. 2016;37(2):152-8. https://doi.org/10.1016/j.evolhumbehav.2015. 10.002 .

16. Weber SR, Pargament KI. The role of religion and spirituality in mental health. Curr Opin Psychiatry. 2014;27(5):358-63. https:// doi.org/10.1097/YCO.0000000000000080.

17. Krause N, Pargament KI, Hill PC, Ironson G. Assessing the role of race/ethnicity in the relationships among spiritual struggles, health, and well-being. Am J Orthop. 2018;88(2):132-41. https://doi.org/ 10.1037/ort0000255.

18. Lukachko A, Myer I, Hankerson S. Religiosity and mental health service utilization among African-Americans. J Nerv Ment Dis. 2015;203(8):578-82. https://doi.org/10.1097/NMD. 0000000000000334 .

19. Neighbors HW, Woodward AT, Bullard KM, Ford BC, Taylor RJ, Jackson JS. Mental health service use among older African Americans: the National Survey of American Life. Am J Geriatr Psychiatry. 2008;16(12):948-56. https://doi.org/10.1097/JGP. 0b013e318187ddd3.

20. Whaley AL. Cross-cultural perspective on paranoia: a focus on the black American experience. Psychiatr Q. 1998;69(4):325-43.

21. Schwartz RC, Blankenship DM. Racial disparities in psychotic disorder diagnosis: a review of empirical literature. World J Psychiatry. 2014;4(4):133-40. https://doi.org/10.5498/wjp.v4.i4. 133.

22. Akinyemi E, Watkins DC, Kavanagh J, Johnson-Lawrence V, Lynn S, Kales HC. A qualitative comparison of DSM depression criteria to language used by older church-going African-Americans. Aging Ment Health. 2018;22(9):1149-55. https://doi.org/10.1080/ 13607863.2017 .1337717$.

23. Roman NV, Mthembu TG, Hoosen M. Spiritual care-'a deeper immunity'-a response to COVID-19 pandemic. Afr J Prim Health Care Fam Med 2020;12(1). https://doi.org/10.4102/phcfm.v12i1. 2456.

24. Owens C. How National Black Muslim COVID Coalition serves communities during the pandemic. The Philadelphia Inquirer. https://www.inquirer.com/news/coronavirus-national-blackmuslim-covid-coalition-ramadan-faith-resources-20200513.html. Accessed Sept 8, 2020.

25. Ribeiro MRC, Damiano RF, Marujo R, Nasri F, Lucchetti G. The role of spirituality in the COVID-19 pandemic: a spiritual hotline project. J Public Health (Oxf). 2020. https://doi.org/10.1093/ pubmed/fdaa120.

26. Del Castillo FA, Biana HT, Joaquin JJB. ChurchInAction: the role of religious interventions in times of COVID-19. J Public Health (Oxf). 2020;42(3):633-4. https://doi.org/10.1093/pubmed/fdaa086.

Publisher's Note Springer Nature remains neutral with regard to jurisdictional claims in published maps and institutional affiliations. 